\title{
REVIEW
}

\section{Species richness of marine soft sediments}

\author{
John S. Gray* \\ Department of Biology, University of Oslo, Pb 1064, Blindern 0316, Oslo, Norway
}

\begin{abstract}
Marine soft sediments comprise one of the largest and oldest habitats in the world, yet remarkably little is known about patterns of species richness. Here I present a short review of patterns of species richness and possible factors that influence such patterns. Species richness in general is remarkably high in both shallow coastal areas and the deep sea. However, there are clear differences - the deep-sea has higher number of species for a given number of individuals than the coast. This can be explained by the larger amounts of primary production that reach coastal compared with deep-sea sediments, leading to higher numbers of individuals per unit area. Species density (the number of species per unit area) is also higher in the deep-sea than in coastal areas, but it is not obvious why this is so. Most studies of the broad patterns of species richness have used samples taken at small scales only. The problem with such analyses is that unless a large number of samples are taken, the true underlying pattern (or lack of it) may be wrongly interpreted. Recent studies have analysed species richness at larger scales. In general there seems to be a cline of increasing species richness from the Arctic to the tropics, but this is not the case in the southern hemisphere, where Antarctic species richness is high. However, it is not known whether high species richness in the Antarctic occurs at all spatial scales. To what extent these patterns are determined by evolutionary factors remains to be determined by the application of molecular methods. The available evidence suggests that environmental factors such as productivity, temperature, and sediment grain-size diversity play dominant roles in determining patterns of regional-scale species richness and patterns in species turnover, and it is probably the regional scale that primarily determines local species richness.
\end{abstract}

KEY WORDS: Diversity $\cdot$ Deep sea $\cdot$ Coasts $\cdot$ Patterns $\cdot$ Scales

\section{INTRODUCTION}

There has been much controversy over whether deep-sea soft sediments have higher species richness than coastal sediments. Recent data suggest that there are real differences, but that such differences may vary with the spatial scales considered. Here, the new findings are examined primarily in the context of macroecological patterns, that is, at large scales. It must be recognised, however, that knowledge of this vast habitat is piecemeal at best. It has been estimated that the total number of samples taken of the deep-sea floor

*Email: j.s.gray@bio.uio.no covers the area of only a few football pitches. Coastal areas have been much better sampled as they are widely used for monitoring the 'health' of coastal systems. The reason why the fauna of marine sediments is preferred for monitoring to that of pelagic systems is that an average sample taken by a grab covering $0.1 \mathrm{~m}^{2}$ in coastal temperate areas will contain over 50 species of macrofauna (animals retained on a sieve with $1 \mathrm{~mm}$ diameter holes). Since the species found in marine sediments cover a wide range of feeding and reproductive types and most are non-motile, effects of contaminants and other disturbances will affect some species and so detection of change is relatively easy using multivariate statistical methods (Clarke \& Warwick 1994, Gray et al. 1990). 
Sediments also contain a rich fauna of small organisms (meiofauna) that pass through the $1 \mathrm{~mm}$ diameter holes but are retained on a sieve with $0.062 \mathrm{~mm}$ holes. Giere (1988) has reviewed this fauna and estimates that there are ca. 40000 species covering a wide variety of phyla. Nematodes account for half the total number of species and some workers estimate that there may be millions of species of nematodes to be found in the unsurveyed deep sea (Lambshead 1993). With the exception of Lambshead's studies (1993), there have been no studies of meiofauna that have treated species richness in a comparative way, and so this fauna will not be discussed here.

Sediments also provide $3 \mathrm{D}$ habitats that act as substrata for other organisms. The simplest structure is of mats of diatoms on the sediment surface in euphotic areas of the inter- and subtidal zones. These mats are associated with diverse bacterial and protozoan assemblages. Seagrasses are rooted in soft sediments in shallow areas of tropical and temperate areas and contain rich species assemblages (Hutchings 1993, Dawes et al. 1995, Hily \& Bouteille 1999, Lee et al. 2001). The widely varied tube structures of annelid worms and organisms such as sea-pens (Pennatulacea) project above the surface, altering water flow and thus altering structure of the sediment. Beds of bivalve mussels and oysters provide more complex structures, with a rich variety of species of attached fauna, (Suchanek 1992, Van Dover \& Trask 2000). Perhaps the most spectacular of these secondary habitats are provided by sponges on soft subtidal sediments in Antarctica (Arntz et al. 1997) and to a lesser extent in the Arctic (Dayton et al. 1994). The sponges may be up to a metre or more in height and are associated with an extremely rich epifauna. I will not consider these secondary habitats further, but instead confine my review to the species richness of the macrofauna of soft sediments, covering scales of richness, variations with depth and latitude and possible mechanisms controlling the observed patterns There are very many studies of the species richness of marine soft sediments and no attempt has been made to review all the literature, but rather to present data from representative and/or recent quantitative surveys. Whilst the data are probably representative of intertidal and coastal areas in temperate regions, quantitative data from the deep-sea and especially from sub-tropical and tropical areas are extremely sparse.

Marine sediments are derived primarily from either wind driven sediments, e.g. the red clays providing much of the floor of the deep sea or from biogenic material from tests of sedimenting plankton. Sandy sediments are usually transported to the ocean from glacial processes during ice ages, erosion from rocky marine areas and large amounts are transported to the coastal ocean by rivers. Beaches exposed to oceanic waves are steep with coarse sediments, which are highly mobile and are an inhospitable habitat for biota. Sheltered areas with fine sand and mud are more species rich. The deep-sea bed below the continental slope is by far the largest sedimentary habitat, and mostly comprises extremely fine muddy sediments broken by the merging edges of continental plates with uplifted rocky mountains. On continental shelves in temperate regions there are a wide variety of sediments, varying from coarse gravels and shell gravels to silt-clay and mud. Isolated pockets of shell-gravel sediments are found the world over and these sediments have very high species richness. In the tropics and subtropics most continental shelves are dominated by mud (over $50 \%$ ), mostly of algal origin (Hayes 1967), whereas at $60^{\circ} \mathrm{N}$ only $10 \%$ is mud. There are large muddy areas outside the major tropical rivers and often the large mud banks change seasonally, being stirred up in the monsoon season (Alongi 1990). The other dominant sediment in tropical areas is carbonate sand of 2 main types, protected shelf lagoons and open shelves. Coastal lagoons form behind barrier islands, which occur in many tropical and subtropical area. In arid areas such as the Persian Gulf, hypersaline conditions occur in the lagoons. Lagoons, however, are not confined to tropical and subtropical areas and are also common in, e.g. the Baltic Sea and on the US east coast (Barnes 1980). One of the characteristic features of sedimentary habitats on continental shelves and in the deep sea is that one single type of sediment often covers many thousands of $\mathrm{km}^{2}$. Thus an interesting ecological aspect is what are the diversity patterns over these very large scales?

In this review I treat large data sets in a comparative manner. There are, of course, problems with such an approach in that the data were not collected for such a purpose and the data are widely different in spatial coverage, sorting methods, and quality of taxonomic expertise used in species determinations etc. These points must be born in mind when reading this review, as at best, it generates ideas rather than providing definitive statements.

\section{MEASUREMENT AND COMPARISON OF SPECIES RICHNESS}

Sanders (1968) first studied the variability in species richness of marine soft sediments with latitude and depth. This benchmark paper stimulated a debate that has continued until today. Whilst Sanders had relatively few data sets with which to make comparative studies, many more are now available. Sanders' main conclusions were that there were 2 clines in species 
richness in marine soft sediments, an increase in richness from poles to tropics and an increase in richness from shallow to deep-sea areas. However, Abele \& Walters $(1979 a, b)$ heavily criticised Sanders conclusions, pointing out that the data were not comparable as the taxa used in the analysis varied greatly as a proportion of the total species richness, and that different sampling gears were used in different areas.

In his seminal paper, Sanders (1968) compared semiquantitative samples taken with an anchor dredge. This sampler digs into the sediment surface, is dragged along the seabed, and the samples are therefore from an unknown area. Sanders identified and counted all the individuals to species. Because the amount of material varied between samples, he developed a method called rarefaction to compare samples of different sizes. Rarefaction is based on drawing random samples of individuals from the distribution pattern of individuals among species in the total sample to obtain an estimate of the total number of species in a smaller sample of individuals. Hurlbert (1971) corrected an error in Sanders' (1968) method and Hurlbert's rarefaction method has become the standard way to compare samples of different sample sizes. The basic assumptions for use of the rarefaction method are that a random distribution of individuals occurs and that dominance does not vary with increasing sample size. Yet nearly all benthic species are distinctly aggregated with high variance: mean ratios and dominance always decreases with sample size (Fager 1982, Gage \& May 1993, Gray 1997). Thus, application of rarefaction to benthic data sets is of doubtful validity yet is still widely used. In most cases, however, the data collected are not from a single large sample but from a number of quantitative samples taken with a grab, corer or box-corer. Data from such samples can be used to plot species accumulation curves, which are much preferred to rarefaction methods for comparing samples of different sizes, and have been used in some studies (Gray et al. 1997). Fig. 1 illustrates, for a regional scale data-set from the continental shelf of Norway, the overestimation in the rarefaction curve compared with the species accumulation curve. For a small sample size of, e.g. $2.5 \mathrm{~m}^{2}$ the overestimate is ca. 100 species (350 compared with 250).

Although the sampled area is only $50.5 \mathrm{~m}^{2}$, these data were from 5 regions spread over $15^{\circ}$ of latitude along the Norwegian continental shelf (Ellingsen \& Gray 2002). Thus the curve represents accumulated species richness over a very large area. Where small numbers of samples have been taken from large areas, as is the case with many marine data sets, a semi-log relationship between species richness and log area is expected, rather than the log-log relationship found when taking nested samples, as is often done with ter-

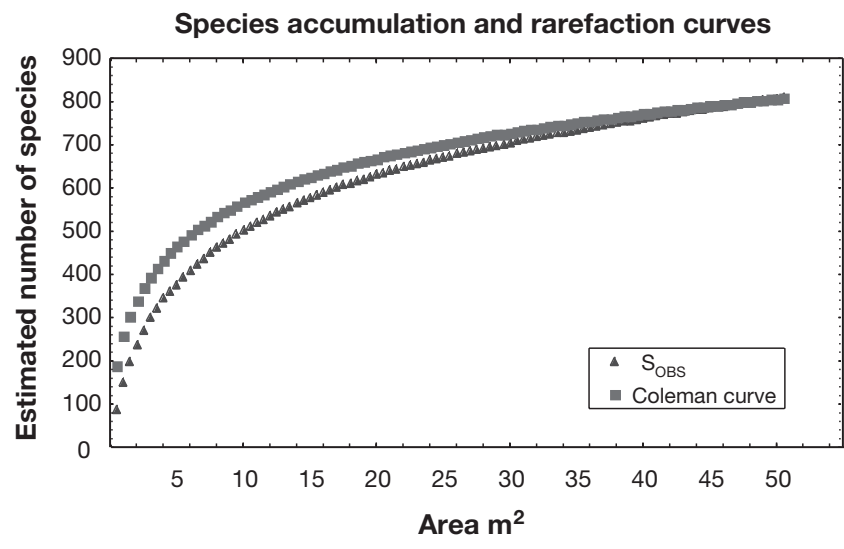

Fig. 1. Species accumulation and rarefaction curves (Coleman curve) for benthic fauna of the Norwegian continental shelf estimated using the EstimateS software of Colwell ${ }^{1} . S_{\text {obs }}$ is the mean estimated number of species after 100 randomisations of the data for each sample size and accumulated up to the total sample size. Confidence intervals are omitted for clarity. The data are from Ellingsen \& Gray (2002). $Y=400.099$ $(\log 10 A)+114.939, R^{2}=0.993$

restrial systems (Rosenzweig 1995). Thus a semi-log (or similar) relationship, as shown in Fig. 1, is likely to be the rule for data on subtidal soft sediment assemblages. In Fig. 1 there is clearly no tendency to approach an asymptote. This is the general rule, as when larger areas are sampled, additional new species are found, and because one always samples very small fractions of the total area of sediment available, an asymptote will not be reached. Therefore, Levin et al. (2001) are mistaken in their statement (p. 71) that 'comparisons should be made only at the asymptote of a species accumulation curve', because both coastal and deep-sea data sets fit similarly-shaped species accumulation curves and neither coastal nor deep-sea data reach asymptotes. This is especially well illustrated in Levin et al.'s (2001) data in their Fig. 5, which shows that neither the data from the deep-sea nor from the shallow George's Bank approach asymptotes. However, the deep-sea data and coastal data differ in that the species accumulation curve is usually steeper for the deep-sea data compared with that from coastal areas.

Once the species accumulation curve has been calculated it is possible to extrapolate to a larger area, if one is interested in estimating the total number of species present in an area. An extrapolation to the area of the Norwegian continental shelf, based on the equation in Fig. 1, predicts 1327 species. The continental

${ }^{1}$ R.K. Colwell (2001) EstimateS: statistical estimation of species richness and shared species from samples. Version 6 . User's guide and application, available at: http://viceroy.eeb.uconn.edu/estimates 


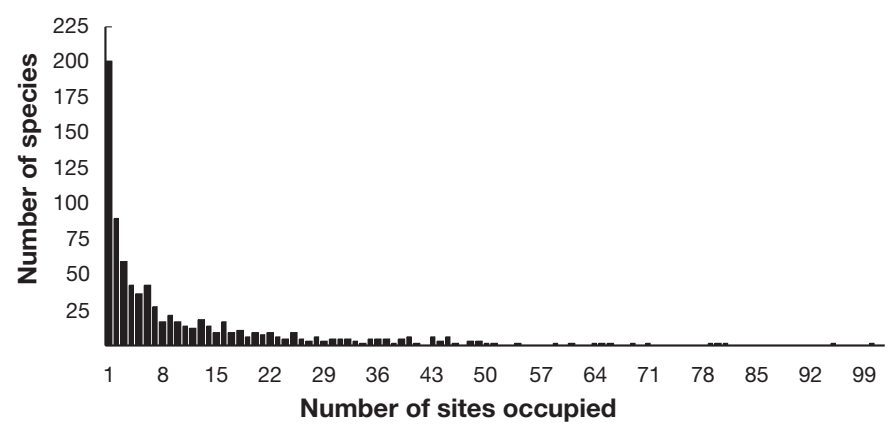

Fig. 2. Species ranges for the macrofauna of the Norwegian continental shelf from Ellingsen \& Gray (2002)

shelf of Norway is routinely surveyed, and the known number of species of benthos is ca. 2500 species from a total area sampled of $1071 \mathrm{~m}^{2}$; thus more species are found than are predicted. In Colwell's EstimateS program $^{1}$, Colwell includes a number of more preferable methods for estimating the total number of species in a given area, but in our experience all give large underestimates of the actual number of species present (Ellingsen \& Gray 2002).

One of the major factors affecting species accumulation curves is how the species are distributed over area. There are relatively few studies that have considered the ranges of marine species, but see Price et al. (1999). Engle \& Summers (1999) in their study of the fauna of US East coast estuaries found that of the 535 species studied, 344 were confined to $1^{\circ}$ of latitude. Species ranges for the same data set used in Fig. 1 from the Norwegian continental shelf (total 809 species) are shown in Fig. 2 (Ellingsen \& Gray 2002). The data show that no species occurs at all sites and only 18 species $(2.2 \%)$ were represented at more than 50 sites. Most

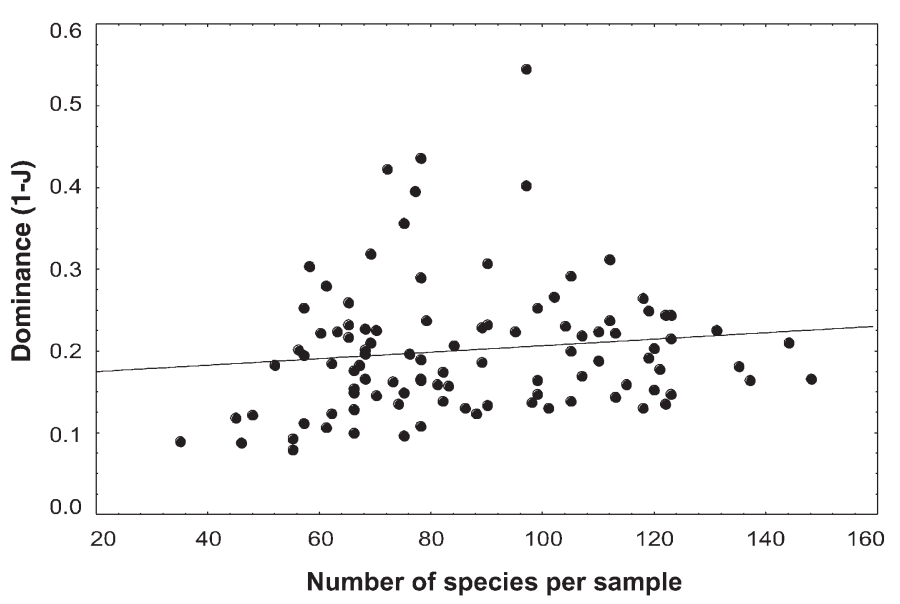

Fig. 3. Relationship between dominance measured as the Berger-Parker Index (1-J) and number of species per sample for data from the Norwegian continental shelf species were restricted to 1 site (200 species) or 2 sites (83 species) only and 158 species were singletons, represented by a single individual. This finding is probably typical for marine data. The patterns of species richness are highly dependent, therefore, on rare species, and yet knowledge of the biology even of most of the common species is severely limited.

In a neglected paper, Birch (1981) made the interesting observation that for the sediment-living fauna for which he had data, dominance increased with species richness. Terrestrial data show an inverse relationship where dominance decreases in more species-rich communities (MacArthur 1969, Odum 1971, Hill 1973). Analysis of data from the Norwegian continental shelf (Fig. 3) shows no relationship between richness and dominance.

\section{GENERAL PATTERNS OF SPECIES RICHNESS}

Table 1 shows recent data on species richness of macrofauna from marine sediments. For coastal sediments the fauna are usually defined as species retained on a sieve with 1 or $0.5 \mathrm{~mm}$ holes, but it is important to note that the fauna of the deep-sea is smaller than that of coastal sediments, and usually sieves with 0.3 or $0.5 \mathrm{~mm}$ diameter holes are used. As far as possible the data have been selected to represent areas that are subjected only to natural disturbances. Some, such as the eutrophic Swedish fjords and the heavily trawled sediments of Hong Kong, are included to illustrate how species richness is affected by such disturbances. For the Norwegian continental shelf, only data from control stations not subjected to effects of oil and gas exploration are used. For many data sets however, there is little information provided on levels of disturbance and trawling is likely to have impacted the fauna of soft sediments in many areas.

\section{Intertidal areas}

Table 1 shows that intertidal sandy beaches exposed to high wave action are impoverished habitats with low numbers of species. In a survey of 105 beaches (Bally 1981), the mean number of macrofaunal species exposed to high, medium and low wave action were 11, 17 and 30, respectively, with abundances increasing from 400, 752 and $1710 \mathrm{~m}^{-2}$ at the 3 levels of exposure. Bivalves of the genus Donax and crabs of the genus Emerita dominate in subtropical and tropical areas and can reach very high abundances and biomass (Brown \& MacLachlan 1990). On beaches subjected to oceanic swell (Australia, S. Africa, Oregon, USA), species richness increased from reflective shores with high wave 


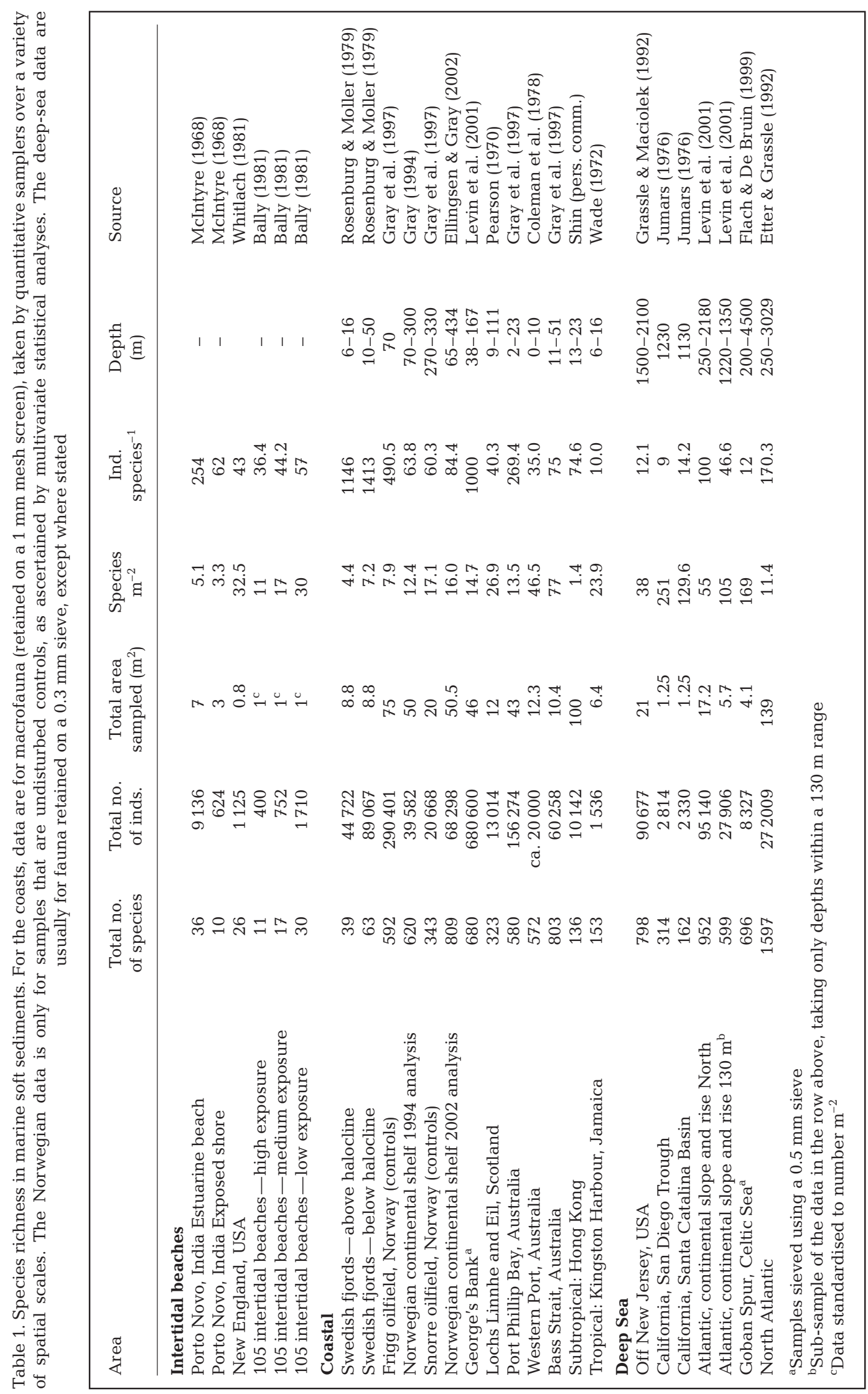


action to dissipative shores with lower wave action and varied inversely with beach slope, an index of wave harshness (Brown \& MacLachlan 1990). Although the number of data sets is few, it is likely that there is no obvious difference between richness of exposed sandy beaches in tropical and temperate areas.

\section{Subtidal areas}

Use of sieves to extract fauna induces an element of selectivity. The reason $1 \mathrm{~mm}$ pore-size screens are used in coastal areas is because coastal sediments are usually coarser than those of deep-sea, thus finer screens would be easily clogged. In addition, the fauna from the deep-sea is smaller than in coastal areas and the sediment on average finer, thus the assumption made in presenting the data in Table 1 is that comparable proportions of fauna are sampled by the respective sieve sizes. Comparisons made between data collected on coarser screens in coastal areas with data collected with finer screens from deep-sea samples gives a highly conservative comparison; had finer sieves been used, more species would have been found in the coastal samples.

Table 1 shows that the total number of species found in the subtidal areas studied are comparably high in surveys from coastal and deep-sea areas ranging to over 800 species in both. Not all deep-sea and subtropical areas are species rich, e.g. the Santa Catalina basin has relatively low species richness, (Jumars 1976) and the highly disturbed sediments in Hong Kong have low species richness (Shin unpubl.) The key questions are not whether there are similar total numbers of species present in an area but how species richness varies with the numbers of individuals and over different spatial scales. Gottelli \& Colwell (2001) have reviewed how species richness can be compared and conclude that 2 aspects need to be considered, species density (the number of species per unit area) and how species richness varies with the number of individuals sampled. For relevant software see R. K. Colwell ${ }^{1}$ and N. Gotelli \& G. L. Entzminger ${ }^{2}$.

The clearest difference between shallow coastal areas and the deep-sea is the much higher number of individuals per species in coastal areas (mean 335.6) compared with the deep-sea (mean 52). One comprehensive data set from a tropical coastal area (Kingston Harbour) has a comparably very low number of individuals per species, 10 , to that of the deep-sea. The

\footnotetext{
${ }^{2}$ N. Gotelli \& G. L. Entzminger (2001) ECOSIM: Null models software for ecology, Version 6, 0. Acquired Intelligence \& Kesey-Bear, available at http//:homepages.together.net/gentsim/ ecosim.htm.
}

Frigg data shows very high numbers of individuals per species. In the year of the survey there was a large dominance by Owenia fusiformis $(37.7 \%$ of the total number of individuals, 290401 ) over the whole Frigg field, and much of the Norwegian continental shelf, thus giving the high mean number of individuals per species, and this may have led to a reduction in the total number of species $\mathrm{m}^{-2}$. The George's Bank data shows that whilst the mean number of species per $\mathrm{m}^{2}$ is similar to many other coastal areas, the mean number of individuals per species is high (1000).

Table 1 shows that for samples from small areas, species density (the number of species per unit area) appears to be very high in the deep sea (38 to 251 species $\mathrm{m}^{-2}$ ). Coastal data from the Bass Strait for a $10.4 \mathrm{~m}^{2}$ sample had a species density within this range (77 species $\mathrm{m}^{-2}$ ); otherwise all the coastal data had lower species densities. The southern coast of Australia, along the adjacent Great Australian Bight is unusual in that reverse estuaries occur where evaporation is larger than freshwater input. Thus there is no sediment discharge from rivers to the coasts and the sediment of the continental shelf is largely comprised of biogenic material (shells, calcareous tubes, etc.), which has extremely rich fauna. This may be related to the heterogeneity of such sediment which is characterised by high grain size diversity with extremely poor sorting, but also these sediments are probably geologically old and highly stable, all of which contribute to the development of high species richness.

Comparisons of species density are not straightforward. I believe that it is an interesting question to ask whether or not species density varies with the area sampled in a variety of different geographical regions and marine areas. As larger areas are sampled and the samples are pooled, so species density decreases. This is of course a natural outcome of the species accumulation curve shown in Fig. 1; more individuals need to be counted and larger areas investigated to encounter new species, but the rate of encounter decreases with increasing area sampled, hence species density declines. But is there a minimal value for different areas and are there differences in species density between, e.g. coastal and deep-sea areas?

Excluding data from highly disturbed areas such as Swedish fjords and Hong Kong, Table 1 shows clearly that in coastal areas where the sampled areas are large (areas of 43 to $75 \mathrm{~m}^{2}$ ), species density is remarkably constant, ranging only between 7.9 to 16.0 species $\mathrm{m}^{-2}$. For the deep-sea Atlantic continental slope data, whereas species density was 105 for a sub-sample of a restricted range of depths for the complete sample a lower value 55 species $\mathrm{m}^{-2}$ was recorded. These values are much higher than that for similar-sized samples of coastal areas. However, Etter \& Grassle (1992) com- 
pared box-core samples over $139 \mathrm{~m}^{2}$ of the deep sea, and here species density was comparable to 11.4 species $\mathrm{m}^{-2}$ of coastal areas. This is the only dataset from the deep-sea where information on species richness over a large-scale is available. The finding of similar species density in the deep sea to that the coastal areas is a surprising result, which perhaps suggests that patterns of species density differ only at small scales and at large scales, species density is comparable in coastal and deep-sea areas.

\section{Gradients of species richness}

Two major gradients of species richness have been described in the fauna of soft sediments: depth and latitude. There are many studies showing that assemblage structure, rather than species richness, varies with small depth ranges, e.g. Bergen et al. (2001). Over larger scales the general pattern is that species richness changes with depth increasing from ca. $200 \mathrm{~m}$ to 1500-2500 $\mathrm{m}$ and then decreasing as depth increases to $5000 \mathrm{~m}$ or more (Rex et al. 1993, 2000, Gray et al. 1997), giving a unimodal curve. However, Levin \& Gage (1998) did not find such a pattern in the East Pacific. Often sediment properties also vary with depth so the change in species richness may not in fact be related to depth alone. Etter \& Grassle (1992) demonstrated that species richness, at sample and regional scales and for all samples from the Atlantic deep-sea, was correlated with depth but also with particle size diversity, and when particle size diversity was held constant there was no correlation between species richness and depth. Pineda (1993) tested hypotheses relating to the depth gradient from the edge of the continental shelf to bathyal depths and showed that the most species rich assemblages occurred where bathymetric ranges were broadest, and suggested that the unimodal depth pattern observed in deep-sea fauna may not be a response to a gradient. An alternative explanation is the Mid Domain Effect (Pineda \& Caswell 1998), where sets of species are constrained within 2 boundaries leading to highest species richness in the mid-zone between boundaries. Pineda \& Caswell (1998) tested deep-sea data from 30 to $60^{\circ} \mathrm{N}$ in the $\mathrm{N}$ Atlantic and showed that for gastropods and polychaetes the Mid Domain model did not hold, and the results were interpreted to show that the observed depth patterns result from non-random distributions of species.

The other gradient in species richness that is described is the latitudinal cline of increasing richness from the Arctic to the tropics for deep-sea fauna (Rex et al. 1993, 1997, 2000) and coastal fauna (Gray et al. 1997). Rex et al. (1993) and Attrill et al. (2000) have analyzed sample species-richness data from benthic sediment-living fauna in the deep sea and estuaries respectively over large geographical scales in the $\mathrm{N}$ and $\mathrm{S}$ Atlantic and show a cline of increasing richness from the pole to the tropics. Attrill et al.'s data, however, ranged between only 2 and 23 species per estuary (pers. comm.), extremely low numbers of species compared with studies in Table 1. Other authors, however, did not find such a cline in the northern hemisphere, (Kendall \& Aschan 1993, Lambshead 1993). The main problem with all these analyses is that they have used point- or sample-species richness only. In the context of this paper, point-species richness is the richness of a single grab or core sample (Whittaker 1975, Gray 2001). Since a single sampling unit cannot be expected to give an estimate of species richness of an area, a series of sampling units are usually combined into a sample in a statistical sense (e.g. 4 or 5 replicate grabs taken at one site). However, very many samples are needed to show trends in point- or sample species richness. A recent study by Engle \& Summers (1999) of 37 estuaries along the east coast of the USA, covering $17^{\circ}$ of latitude, covered 535 genera and found distinct assemblages from North to South, but no clear latitudinal gradient of species richness. At small scales ( $1^{\circ}$ of latitude) salinity, sediment grain size, and small differences in depth affected species richness. Recently Ellingsen \& Gray (2002) have compared large areas of the continental shelf of Norway covering a latitudinal band of $15^{\circ}$, from 56 to $71^{\circ} \mathrm{N}$ and from 1 to $23^{\circ} \mathrm{E}$ longitude. Sample-species richness measured in 101 samples did not show any latitudinal trend and was highly variable, varying from 35 to 148 species per sample. The species richness of large areas (5 areas between 9100 and $22000 \mathrm{~km}^{2}$ ) did not show a latitudinal gradient either, and in fact the most southern area of the North Sea at 56 to $57^{\circ} \mathrm{N}$ had lowest richness, the highest was at 60 to $61^{\circ} \mathrm{N}$ and the second highest off the coast of Finnmark at 70 to $71^{\circ} \mathrm{N}$, off northern Norway.

Rex et al. (1993) examined deep-sea data both at the sample scale and within $3^{\circ}$ latitudinal bounds and showed that there was a cline of increasing richness from the Arctic to the tropics in the gastropod family Turridae. Likewise, Roy et al. $(1996,1998)$ have assembled very large data sets on gastropod snails, from all habitats, not just soft sediments, occurring in coastal areas of the East and West coasts of the USA. They found clear latitudinal clines of increasing richness from the Canadian Arctic ( 80 to $85^{\circ} \mathrm{N}$ ) to the tropics in both coasts. However, the highest species richness occurred not in the tropics but between 20 and $30^{\circ} \mathrm{N}$. Rex et al.'s data (1993) also suggested that for bivalves and gastropods there was no cline from the tropics to $40^{\circ} \mathrm{N}$, but thereafter species richness declined with latitude 
and was especially low in the Norwegian Sea at 72 to $75^{\circ} \mathrm{N}$. Most of the studies described above are confined to the Northern hemisphere. What little is known of the Southern hemisphere suggests that there is no clear evidence of a cline of increasing richness from Antarctica to the tropics (Clarke 1992), but that there are hot-spots of high species richness in coastal areas of Australia (Gray et al. 1997), and Antarctica has high species richness (Arntz et al. 1997). Likewise, Crame's $(2000 a, b)$ important analyses of total bivalve species richness, which includes habitats other than sediments, show clearly that the highest richness is in the tropics and centered in the Indonesian archipelago.

\section{EXPLAINING THE PATTERNS}

Low species richness is found where the habitat is subjected to constantly fluctuating environmental conditions, such as intertidal beaches with high wave action, and few species have adapted to such habitats over evolutionary time. The Baltic Sea is the largest brackish water area in the world and is characterised by large gradients of salinity. The salinity of the open sea is around 35 psu whereas in the central Baltic it is ca. 5 psu and under 3 psu in the Gulf of Bothnia. The numbers of species of benthic macrofauna decrease from ca. 1500 in the Skagerrak, to 50 in the central Baltic Sea and to less than 10 in the Gulf of Bothnia (Elmgren \& Hill 1997). It is a widely held misconception that low salinity areas have low species richness because low salinity is a stress factor. Both the Baltic Sea and most estuaries are geologically young and there has not been sufficient time (a mere $5000 \mathrm{yr}$ for the Baltic Sea) for colonisation from the regional species pool to occur. With the exception of a few species recently introduced from the Caspian Sea, most Baltic Sea species are simply representatives of the fauna of the neighbouring sea areas, the Kattegat and Skaggerak. Likewise, species richness is low in areas where high salinities dominate (e.g. the Arabian Gulf, Price 1982, Sheppard et al. 1992), again because species have not yet had sufficient evolutionary time to adapt to the conditions.

Data from large-scale studies (Table 1) in general show 4 major patterns that: (1) deep-sea areas have lower numbers of individuals per species than coastal areas; (2) species density is higher in the deep sea than coastal areas at local scales but similar at large scales; (3) species richness shows a unimodal pattern with depth, increasing from the edge of the continental shelf to bathyal depths (1500 to $2500 \mathrm{~m}$ ) and then decreasing to abyssal depths; (4) species richness shows a decreasing cline from the subtropics to the Arctic, but not in the southern hemisphere.
To what extent can these patterns be related to a common causal factor? In terrestrial systems, Wright's (1983) energy hypothesis has found favour as the primary factor controlling the patterns in species richness of many terrestrial plant and animal taxa (Kerr \& Packer 1997, Kerr 2001). Wright reinterpreted the species-area relationship to an energy-area relationship showing that tropical regions received the greatest inputs of energy and polar-regions the least. The energy input to a given area may be measured as temperature, insolation, or most successfully for plant species richness as an index of evapotranspiration. In a marine context productivity has been used as a proxy for energy input (Pearson \& Rosenberg 1987). Fraser \& Currie (1996) showed convincingly that the speciesrichness-energy relationship also applied to corals, and that annual ocean temperature was the best environmental predictor of regional generic richness.

The lower number of individuals per species in the deep-sea compared with the coast is likely to be related to productivity since there is a general decrease in particulate organic matter (POM) flux from the continental shelf to abyssal depths (Suess 1980, Martin et al. 1987, Honjo et al. 1995). Lower food resources will support smaller population sizes in the deep-sea compared with the coast. Likewise the unimodal pattern of richness with depth has been related to productivity. Levin et al. (2001) argue that at the lowest food supply (abyssal depths), species richness is low because there are insufficient resources to support viable populations of many species. As food supply increases, species richness increases because more species can maintain viable populations. They argue that in the most food rich area (coasts), species richness declines due to increased food resources supporting larger populations, leading to dominance by a few species and/or a decrease in habitat heterogeneity. At present no tests have been made on the hypothesis that there are differences in assemblage structure (the distributions of individuals among species) between abyssal and bathyal depths and coastal areas. I suggest that Levin et al.'s model would predict that plots of individuals per species against number of species would show increasing numbers of dominant species from abyss to bathyal to coastal areas and fewer rare species at abyssal compared with bathyal depths.

Rex \& Etter (1998) noted that, contrary to expectation, at small scales over a range from 250 to $2250 \mathrm{~m}$ in the North Atlantic, species density of gastropods decreased linearly with depth from coast to abyss and was accompanied by a steep drop in number of individuals per unit area. They suggested that decreased food input with increasing depth selectively favours increased size because there are metabolic and competitive advantages to both larvae and adults. They 
also proposed that the potential for species radiation is highest at bathyal depths, where the selective gradient is steepest and there is more opportunity for geographic isolation and where food resources permit a higher level of coexistence than in the abyss.

Another variable that is correlated with the unimodal pattern of species richness with depth is sediment particle diversity (Whitlach 1981, Grassle 1989, Etter \& Grassle 1992). Grassle's (1989) spatial-temporal mosaic theory suggests that most sediment living species are able to respond to subtle differences in sediment particle structure either as larvae or adults seeking a preferred substratum. The deep-sea sediment infauna however, has a much smaller average size than that of coastal sediments. It is argued that these smaller species respond to finer gradients of sediment heterogeneity than do coastal species, thus leading to higher species density in the deep-sea. Grassle further suggested that small-scale discrete disturbance, operating within the low resource deep-sea environment, maintains high species richness because disturbance is such that at both spatial and temporal scales there are patches at different stages of succession and recolonisation. The scales of patchiness and of disturbance may be larger in coastal areas, also contributing to species density being lower, but this has not been studied in a comparative way. However, Ellingsen \& Gray (2002) showed that on the Norwegian continental shelf there was no relationship between sample species richness and sediment properties such as sorting and percentage silt-clay, yet there were significant relationships at larger areas. The area with the highest large-area species richness had highly variable sediment properties and depth also varied greatly, whereas the shallow and sedimentary uniform North Sea had low large-area species richness. Sorting is controlled by hydrodynamic and/or geomorphological processes which operate over large scales. Thus at larger scales hydrodynamic factors control large-scale sediment properties such as sorting and the associated species richness (Warwick \& Uncles 1980, Thrush 1991). Much progress has been made recently in measurement of sediment properties over large-scales using video and acoustic mapping (Snelgrove \& Butman 1994, Thrush et al. 1997, Ellingsen 2002).

However, a reviewer of this paper claimed that 'all deep sea studies of which I am aware show that most soft-sediment macrofaunal species within a deep-sea site agree on where to be abundant; i.e. only a very small proportion of the total species within a habitat show any evidence of habitat partitioning on any scale'. The evidence, however, is that this statement is untrue. For example, Rice \& Lambshead (1994) and Lambshead \& Hodda (1994) studied the aggregation of nematodes at the phytodetritus-impacted Porcupine
Abyssal Plain site, and showed that $72 \%$ of the species were significantly aggregated in different patches, as predicted by the spatial temporal mosaic hypothesis. Furthermore, Fenchel (2002), in his review of microbial patchiness, shows that in sediments microbial communities are extremely patchy over very small scales. It has been known since the 1960s that sediment-living species respond to patches of individual species of bacteria (Gray 1966). Thus patchiness within the sediment is likely to be a major determinant of species richness at all scales.

In summary, it is likely that available food resources control population densities at a variety of scales and set the maximum range of species richness, but that variability in species richness for a given resource level is determined by spatial and temporal heterogeneity in sediment structure caused by both biological activities and by hydrodynamical and geomorphological factors. Longhurst (1998) has recently attempted to define biogeographical provinces in marine systems using hydrographic features. He gives convincing arguments for the scales and boundaries of systems and, more importantly, for biodiversity studies, key biological characteristics such as temperature and productivity. Whether or not these boundaries correspond to patterns of species richness of sediments is a key unresolved question.

On an evolutionary scale through geological time, bivalve molluscs have become progressively more infaunal, (Stanley 1970, Crame 2000a,b), probably as a response to predation pressures (Vermeij 1978). This process has primarily occurred in the tropics and may be related to the fact that ca. $50 \%$ of the area of the inner continental shelves in the tropics is composed of fine mud, whereas at $60^{\circ} \mathrm{N}$ the proportion is only $10 \%$ (Hayes 1967). Based on work of Stanley (1970), Crame $(2000 a, b)$ suggested that burrowing rates are temperature dependent and that predator avoidance by becoming a burrower is therefore easier in the tropics.

Can the energy-productivity hypothesis also be used to explain the latitudinal gradient of species richness observed in the Northern hemisphere? Rex et al. (1993) suggest that the decline in species richness towards the arctic in deep-sea benthos is related to declining productivity northwards, a view supported by Gage \& May (1993). Yet productivity does not decline northwards. What does decline is the coupling between primary and secondary production, which results in large amount of material settling to the seabed in polar regions (Wassmann 1989). The complex nature of the marine latitudinal gradient is shown clearly by Roy et al. $(1996,1998)$ in comprehensive studies of $\mathrm{N}$ Atlantic and Pacific gastropods. Highest species richness occurred between 20 and $30^{\circ} \mathrm{N}$ on both coasts with lower richness in the tropics and steep declines north of $30^{\circ} \mathrm{N}$ 
latitude. Other data also suggest that in the N Atlantic maximal species richness does not occur in the tropics (Price et al. 1999). This pattern is not consistent with productivity but the data of Roy et al. $(1996,1998)$ show highly significant correlations with seasurface temperature, which is also consistent with Wright's energy hypothesis. There are large-scale patterns in sea-surface temperature, which reflect hydrographic processes, and such systems are also likely to be major determinants of benthic species richness (Longhurst 1998). Data taken at different scales from the Norwegian continental shelf (Ellingsen \& Gray 2002) did not show a latitudinal gradient between 56 and $71^{\circ} \mathrm{N}$, and on the northern most part of the Norwegian continental shelf, species richness is high. Is this high species richness related to high productivity or are other factors important such as historical/evolutionary factors?

An ice sheet covered this area only 15000 yr ago, and at this time the North Sea, which had the lowest species richness, was still land. Following the ice-age colonisation of the continental shelf east of the northern-most area came first from the north and east, and the coast was open to the North Atlantic in midNorway where today richness appears to be highest (Ellingsen \& Gray 2002). In the deep part of the adjacent Norwegian Sea at $4000 \mathrm{~m}$, species richness is low. Does this reflect the fact that species are still 'migrating' to the deep Norwegian Sea from an evolutionary centre to the south as appears to be the case with bivalve molluscs (Crame 2000a,b)?

The same argument relating to evolutionary history may explain the lack of a gradient of decreasing richness polewards in the southern hemisphere (Crame 2000a). It is known that the Antarctic benthos is species rich (Arntz et al. 1997) and yet that there are many taxa that are under-represented such as bivalve molluscs, decapod crustacea and teleost fish. Crame $(2000 a, b)$ suggests that species are still migrating south and equilibrium has not yet been reached. For marine sediments there are remarkably few data sets available from the southern hemisphere (especially from South America and Africa) and for the whole of the tropics. The application of molecular techniques is expected to be especially useful in ascertaining the role of evolutionary and ecological control of these and other species richness patterns.

But how are these patterns of species richness maintained? Terrestrial literature in general shows that there is a positive linear relationship between local and regional species richness (Cornell \& Lawton 1992, Cornell 1999). In terrestrial systems, Srivastava (1999) defines the 2 scales by saying, 'Local richness is measured on a spatial scale small enough that all species could encounter each other within ecological time and so possibly interact. Examples are the number of fish

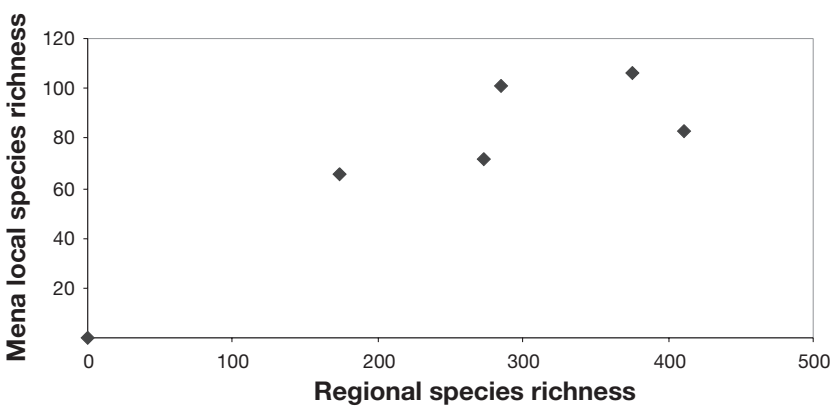

Fig. 4. Regional and local species richness (data from the Norwegian continental shelf, Ellingsen \& Gray 2002). First species accumulation plots were calculated using EstimateS with 50 randomisations. Then linear regressions were fitted of the form $S=z\left(\log _{10} A\right)+C$, where $S=$ number of species and $A=$ area, and $z$ and $C$ are constants. Regional richness was corrected for area as recommended by Srivastava (1999) by using these separate regressions and calculating the number of species found in the smallest comparable area for all regions. For the linear regression in Fig. $4, \mathrm{R}^{2}=0.80$

species in a lake, the number of grass species in a meadow. Regional richness, or the richness of the species pool is measured on a larger spatial scale. The regional species pool contains all the species which could eventually colonise a location if competitive exclusion is unimportant. Examples are the fish species in Britain, the grassland flora of the Serengeti.' Whilst the definitions may be appropriate for terrestrial systems, they are virtually impossible to apply to sediments of the continental shelf or deep-sea. Rex et al. (2000) have defined regions in the deep-sea as basins, whereas Ellingsen \& Gray (2002) have used arbitrary areas of the continental shelf. Species richness varies with scale in the deep-sea and Jumars (1976) showed that species richness varied between and within cores of size $0.01 \mathrm{~m}^{2}$ and at roughly $100 \mathrm{~km}$. In their recent review of deep-sea species diversity, Levin et al. (2001) distinguished scales of species richness varying from 1 to $10 \mathrm{~m}^{2}$, to a larger scale-which they term regional-

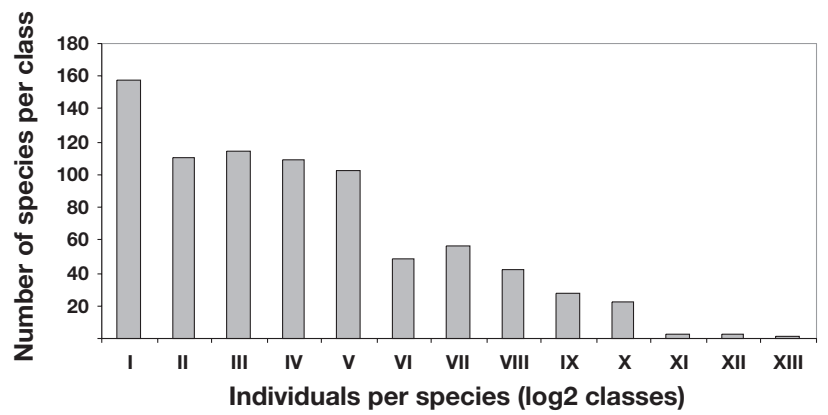

Fig. 5. Plots of individuals per species against number of species in $\log _{2}$ classes for data covering a large area of the Norwegian continental shelf 
of $100 \mathrm{~s}$ to $1000 \mathrm{~s}$ of $\mathrm{m}$. There is no reason to assume that variations in richness in coastal areas do not vary over similar scales $(0.01 \mathrm{~m}$ to $100 \mathrm{~km})$.

There are 3 lines of evidence that suggest, for marine sediment-living fauna, that local species richness is determined primarily by regional richness. Firstly, available marine data sets (Cornell \& Karlson 1996, Rex et al. 2000, Gray 2001) suggest that local species richness is linearly related to regional richness and therefore does not show saturation. Fig. 4 shows the Norwegian data, which are merely suggestive of a linear relationship and many more data points are needed before a full statistical analysis can be made. Likewise, Stuart \& Rex (1994) suggested that for the component of deep-sea fauna they studied (prosobranch molluscs) regional richness was the most significant predictor of species richness explaining over half the variance in the data, with the regional proportion of species with planktotrophic larval development as a subordinate but significant factor. Secondly, from the semi-logarithmic species-area curves found in benthic assemblages, rare species are added as sample size increases and there are large numbers of rare species that occur at densities of one or a few individuals per sampling unit, whatever the scale sampled. This again, does not suggest saturation. Thirdly, plots of individuals per species for the Norwegian continental shelf Fig. 5 show data similar to that for an unsaturated forest reported in 'The unified neutral theory of biodiversity and biogeography' recently proposed by Hubbell (2001). The unsaturated forest is characterised by 'the population dynamics of the individual species being independent of one another' (Hubbell 2001, p. 59).

Such dependence of local species richness on regional richness suggests that most species interactions are weak or that species interactions are strong but do not constrain species richness (Cornell \& Lawton 1992, Cornell 1999, Lawton 1999) and the regional species pool determines local scale richness. Weak interactions are the rule in sediment systems (Reise 1985). The local scale patches created in Grassle's model allow continuous recruitment from the regional species pool, as seems to occur in corals (Cornell \& Karlson 1996). More data are needed on regional-scale patterns in species richness from coastal, deep sea and especially tropical areas, and on how hydrodynamical and geomorphological factors affect large scale sedimentary processes and hence species richness of large areas. Data from the Norwegian continental shelf (Ellingsen \& Gray 2002) show that most species have small ranges (Fig. 2) and assemblages are dominated by species having one or a few individuals per sampling unit. This is a key feature of benthic assemblages and new understanding and models are needed to explain how species with such small population sizes are able to disperse over large areas and thus maintain the high species richness found.

Acknowledgements. I sincerely thank Tom Fenchel, Simon Thrush, Andrew Price, Kari Ellingsen and 3 anonymous reviewers for comments, which have greatly improved this paper.

\section{LITERATURE CITED}

Abele L, Walters J (1979a) Marine benthic diversity: a critique and alternative explanation. J Biogeogr 6:115-126

Abele L, Walters J (1979b) The stability-time hypothesis: revaluation of the data. Am Nat 114:559-568

Alongi DM (1990) The ecology of tropical soft-bottom benthic ecosystems. Oceanogr Mar Biol Annu Rev 28:381-496

Arntz WE, Gutt J, Klages M (1997) Antarctic marine biodiversity. In: Battaglia B, Valencia J, Walton DWH (eds) Antarctic communities: species, structure and survival. Cambridge University Press, Cambridge, p 3-14

Attrill MJ, Stafford R, Rowden AA (2000) Latitudinal diversity patterns in estuarine tidal flats: indications of a global cline. Ecography 24:318-324

Bally R (1981) The ecology of three sandy beaches on the west coast of South Africa. PhD thesis, University of Cape Town

Barnes RSK (1980) Coastal lagoons: the natural history of a neglected habitat. Cambridge studies in modern biology. Cambridge University Press, Cambridge

Bergen M, Weisberg SB, Smith RW, Cadien DB and 6 others (2001) Relationship between depth, sediment, latitude and the structure of benthic infaunal assemblages on the mainland shelf of southern California. Mar Biol 138: 637-647

Birch DW (1981) Dominance in marine ecosystems. Am Nat 118:262-274

Brown AC, McLalchlan A (1990) Ecology of sandy shores. Elsevier, Amsterdam

Clarke A (1992) Is there a latitudinal diversity cline in the sea? Trends Ecol Evol 7:286-287

Clarke KR, Warwick RM (1994) Change in marine communities: an approach to statistical analysis and interpretation. Plymouth Marine Laboratory, UK

Coleman N, Cuff W, Drummond M, Kudenow JD (1978) A quantitative survey of the macrobenthos of Western Port, Victoria. Aust J Mar Freshw Res 29:445-466

Cornell HV (1999) Unsaturation and regional influences on species richness in ecological communities: a review of the evidence. Ecoscience 6:303-315

Cornell HV, Karlson RH (1996) Species richness of reefbuilding corals determined by local and regional processes. J Anim Ecol 65:233-241

Cornell HV, Lawton JH (1992) Species interactions, local and regional processes and limits to the richness of ecological communities: a theoretical perspective. J Anim Ecol 62: $1-12$

Crame A (2000a) Evolution of taxonomic diversity gradients in the marine realm: evidence from the composition of recent bivalve faunas. Paleobiology 26:188-214

Crame A (2000b) The nature and origin of taxonomic diversity gradients in marine bivalves. In: Harper EM, Taylor JD, Crame JA (eds) The evolutionary biology of the Bivalvia. Geol Soc Lond Spec Publ 177:347-360

Dawes CJ, Hanisak D, Kenworthy WJ (1995) Seagrass biodiversity in the Indian River Lagoon. Bull Mar Sci 57:59-66 
Dayton PK, Mordida BJ, Bacon F (1994) Polar marine communities. Am Zool 34:90-99

Ellingsen KE, Gray JS (2002) Spatial patterns of benthic diversity -is there a latitudinal gradient along the Norwegian continental shelf? J Anim Ecol 71:373-389

Ellingsen KE, Gray JS, Bjørnbom E (2002) Acoustic classification of seabed habitats using the QTC VIEW ${ }^{\text {TM }}$ system. ICES J Mar Sci (in press)

Elmgren R, Hill C (1997) Ecosystem function at low biodiversity - the Baltic example. In: Ormond R, Gage J, Grassle JF (eds) Marine biodiversity: patterns and processes. Cambridge University Press, Cambridge, p 319-336

Engle VD, Summers JK (1999) Latitudinal gradients in benthic community composition in Western Atlantic estuaries. J Biogeogr 26:1007-1023

Etter RJ, Grassle JF (1992) Patterns of species diversity in the deep-sea as a function of sediment particle size. Nature 360:576-579

Fager EW (1972) Diversity: a sampling study. Am Nat 106: 293-310

Fenchel T (2002) Microbial behaviour in a heterogeneous world. Science 296:1068-1071

Flach E, De Bruin W (1999) Diversity patterns in macrobenthos across a continental slope in the NE Atlantic. J Sea Res 42:303-323

Fraser RH, Currie DJ (1996) The species richness-energy hypothesis in a system where historical factors are thought to prevail: coral reefs. Am Nat 148:138-159

Gage JD, May RM (1993) A dip into the deep seas. Nature 365:609-610

Giere O (1988) Meiobenthology. Springer-Verlag, Berlin

Gotelli NJ, Colwell RK (2001) Quantifying biodiversity: procedures and pitfalls in the measurement and comparison of species richness. Ecol Lett 4:379-391

Grassle JF (1989) Species diversity in deep-sea communities. Trends Ecol Evol 4:12-15

Grassle JF, Maciolek NJ (1992) Deep-sea species richness: regional and local diversity estimates from quantitative bottom samples. Am Nat 139:313-341

Gray JS (1966) The attractive factor of intertidal sands to Protodrilus symbioticus Giard. J Mar Biol Assoc UK 46: 627-645

Gray JS (1994) Is the deep sea really so diverse? Species diversity from the Norwegian continental shelf. Mar Ecol Prog Ser 112:205-209

Gray JS (1997) Gradients of marine biodiversity. In: Ormond R, Gage J, Grassle JF, (eds) Marine biodiversity: patterns and processes. Cambridge University Press, Cambridge, p 18-34

Gray JS (2001) Marine diversity: the paradigms in patterns of species richness examined. Sci Mar 65:41-56

Gray JS, Clarke KR, Warwick RM, Hobbs G (1990) Detection of initial effects of pollution on marine benthos: an example from the Ekofisk and Eldfisk oilfields, N. Sea. Mar Ecol Prog Ser 66:285-299

Gray JS, Poore GCB, Ugland KI, Wilson RS, Olsgard F, Johannessen $\varnothing$ (1997) Coastal and deep-sea benthic diversities compared. Mar Ecol Prog Ser 159:97-103

Hayes MO (1967) Relationship between coastal climate and bottom sediment type on the continental shelf. Mar Geol 5: $1-132$

Hill MO (1973) Diversity and evenness: a unifying notation and its consequences. Ecology 54:427-432

Hily C, Bouteille M (1999) Modifications of the specific diversity and feeding guilds in an intertidal sediment colonized by an eelgrass meadow (Zostera marina) (Brittany, France). CR Acad Sci Ser III Sci Vie 322:1121-1131
Honjo S, Dymond J, Collier R, Manganini SJ (1995) Export production of particles to the interior of the equatorial Pacific Ocean during the 1992 EQPAC experiment. DeepSea Res Part II 42:831-870

Hubbell SP (2001) The unified theory of biodiversity and biogeography. Princeton University Press, Princeton

Hurlbert SH (1971) The non-concept of species diversity: a critique and alternative parameters. Ecology 52:577-585

Hutchings PA (1993) Infauna of marine sediments and seagrass beds of upper Spencer Gulf near Port Pirie, South Australia. Trans R Soc S Aust 117:1-15

Jumars PA (1976) Deep-sea species diversity. Does it have a characteristic scale? J Mar Res 34:217-246

Kendall MA, Aschan M (1993) Latitudinal gradients in the structure of macrobenthic communities: a comparison of Arctic, temperate and tropical sites. J Exp Mar Biol Ecol 172:157-169

Kerr JT (1997) Habitat heterogeneity as a detrminant of mammal species richness in high-energy regions. Nature 385: 252-254

Kerr JT (2001) Butterfly species richness patterns in Canada: energy, heterogeneity, and the potential consequences of climate change. Conserv Ecol 5:131-147

Kerr JT, Packer L (1997) Habitat heterogeneity as a determinant of mammal species richness in high energy regions. Nature 385:252-254

Lambshead PJD (1993) Recent developments in marine biodiversity research. Oceanis Doc Oceanogr 19:5-24

Lambshead PJD, Hodda M (1994) The impact of disturbance on measurements of variability in marine nematode populations. Vie Milieu 44:21-27

Lawton JH (1999) Are there general laws in ecology? Oikos 84:177-192

Lee SY, Fong CW, Wu RSS (2001) The effects of seagrass (Zostera japonica) canopy structure on associated fauna: a study using artificial seagrass units and sampling of natural beds. J Exp Mar Biol Ecol 259:23-50

Levin LA, Etter RJ, Rex MA, Gooday AJ and 5 others (2001) Environmental influences on regional deep-sea species diversity. Annu Rev Ecol Syst 32:51-93

Longhurst AR (1998) Ecological geography of the sea. Academic Press, San Diego

MacArthur RH (1969) Patterns of communities in the tropics. Biol J Linn Soc 1:19-30

Martin JH, Knauer GA, Karl DM, Broenkow WW (1987) VERTEX-carbon cycling in the Northeast Pacific. Deep-Sea Res Part A 34:267-285

McIntyre AD (1968) The meiofauna and macrofauna of some tropical beaches. J Zool Lond 156:377-392

Odum EP (1971) Fundamentals of ecology. Saunders, Philadelphia

Pearson TH (1970) The benthic ecology of Loch Linnhe and Loch Eil, a sea-loch system on the west coast of Scotland. I. The physical environment and the distribution of the macrobenthoc fauna. J Exp Mar Biol Ecol 5:1-34

Pearson TH, Rosenberg R (1987) Feast and famine structuring factors in marine benthic communities. In: Gee JHR, Giller PS (eds) Organisation of communities past and present. Blackwell Scientific Publications, Oxford, p 373-395

Pineda J (1993) Boundary effects on the vertical ranges of deepsea benthic species. Deep-Sea Res Part A 40:2179-2192

Pineda J, Caswell H (1998) Bathymetric species-diversity patterns and boundary constraints on vertical range. DeepSea Res Part B 45:83-101

Price ARG (1982) Western Arabian Gulf echinoderms in high salinity waters and the occurrence of dwarfism. J Nat Hist 16:519-527 
Price ARG, Keeling MJ, O'Callaghan CJ (1999) Ocean-scale patterns of 'biodiversity' of Atlantic asteroids determined from taxonomic distinctness and other measures. Biol J Linn Soc 66:187-203

Reise K (1985) Predator control in marine tidal sediments. In: Gibbs PE (ed) Proc 19th Eur Mar Biol Symp Plymouth. Cambridge University Press, Cambridge, p 311-322

Rex MA (1993) Global-scale patterns of species diversity in the deep-sea benthos. Nature 365:636-639

Rex MA, Etter RJ (1998) Bathymetric patterns of body size: implications for deep-sea biodiversity. Deep-Sea Res Part B 45:103-127

Rex MA, Etter RJ, Stuart CT (1997) Large-scale patterns of species diversity in the deep-sea benthos. In: Ormond RFG, Gage JD, Angel MV (eds) Marine biodiversity: patterns and processes. Cambridge University Press, Cambridge, p 94-121

Rex MA, Stuart CT, Coyne G (2000) Latitudinal gradients of species richness in the deep-sea benthos of the North Atlantic. Proc Natl Acad Sci USA 97:4082-4085

Rice AL, Lambshead PJD (1994) Patch dynamics in the deepsea benthos: the role of a heterogeneous supply of organic matter. In: Giller PS, Hildrew AG, Rafaelli DG (eds) Aquatic ecology: scale, pattern and process. 34th Symp Brit Ecol Soc. Blackwell Scientific Publications, Oxford, p 469-499

Rosenberg R, Möller P (1979) Salinity stratified benthic macrofaunal communities and long-term monitoring along the west coast of Sweden. J Exp Mar Biol Ecol 37:175-203

Rosenzweig ML (1995) Species diversity in space and time. Cambridge University Press, Cambridge

Roy K, Jablonski D, Valentine JW (1996) Higher taxa in biodiversity studies: patterns from eastern Pacific marine molluscs. Phil Trans R Soc Lond B 351:1605-1613

Roy K, Jablonski D, Valentine JW, Rosenberg G (1998) Marine latitudinal diversity gradients: tests of causal hypotheses. Proc Natl Acad Sci USA 95:3699-3702

Sanders HL (1968) Marine benthic diversity: a comparative study. Am Nat 102:243-282

Sheppard CRC, Price ARG, Roberts CM (1992) Marine ecology of the Arabian region: patterns and processes in extreme tropical environments. Academic Press, London

Snelgrove PV, Butman CA (1994) Animal sediment relationships revisited: cause vs effect. Oceanogr Mar Biol Annu Rev 32:111-177

Editorial responsibility: Otto Kinne (Editor),

Oldendorf/Luhe, Germany
Srivastava DS (1999) Using local-regional richness plots to test for species saturation: pitfalls and potentials. J Anim Ecol 68:1-16

Stanley SM (1970) Relation of shell form to life habits of the Bivalvia (Mollusca). Geol Soc Am Bull 125:1-296

Stuart CT, Rex MA (1994) The relationship between developmental pattern and species diversity in deep-sea prosobranchs snails. In: Young CM, Eckelbarger KJ (eds) Reproduction, larval biology and recruitment of the deep-sea benthos. Columbia University Press, New York, p 118-136

Suchanek TH (1992) Extreme biodiversity in the marine environment: Mussel bed communities of Mytilus californianus. Northwest Environ J 8:150-152

Suess E (1980) Particulate organic - carbon flux in the oceanssurface productivity and oxygen utilization. Nature 288: $260-263$

Thrush SF (1991) Spatial patterns in soft-bottom communities. Trends Ecol Evol 6:75-79

Thrush SF, Schneider DC, Legendre P, Whitlach RB and 9 others (1997) Scaling-up from experiments to complex ecological systems: where to next? J Exp Mar Biol Ecol 216:243-254

Van Dover C, Trask JL (2000) Diversity at deep-sea hydrothermal vent and intertidal mussel beds. Mar Ecol Prog Ser 195:169-178

Vermeij GJ (1978) Biogeography and adaptation. Harvard University Press, London

Wade BA (1972) A description of a highly diverse soft-bottom community in Kingston Harbour, Jamaica. Mar Biol 13: $57-69$

Warwick RM, Uncles RJ (1980) Distribution of benthic macrofauna associations in the Bristol Channel in relation to tidal stress. Mar Ecol Prog Ser 3:97-103

Wassmann P (1989) Sedimentation of organic matter and silicate from the euphotic zone of the Barents Sea. Rapp P-V Cons Perm Int Exp Mer 188:108-114

Whitlach RB (1981) Animal-sediment relationships in intertidal marine benthic habitats: some determinants of deposit-feeding species diversity. J Exp Mar Biol Ecol 53: $31-45$

Whittaker RH (1975) Communities and ecosystems. MacMillan, New York

Wright DH (1983) Species-energy theory: an extension of species-area theory. Oikos 41:496-506

Submitted: April 9, 2002; Accepted: July 19, 2002

Proofs received from author(s): November 5, 2002 